\title{
Home Economics Students' Satisfaction or Dissatisfaction with Learning Experiences in Clothing and Textiles in Tertiary Institutions
}

\author{
D.O.Arubayi \\ Vocational Education Department, Delta State University, Abraka, Nigeria \\ P.O. Box 192, Abraka, Delta State, Nigeria \\ Mobile: +234-8035748839, +234-8025606477, Email: darubayig@yahoo.com
}

KEYWORDS Students' Satisfaction. Tertiary Institutions. Students Appraisal. Learning Experiences. Home Economics Curriculum

\begin{abstract}
The purpose of this research work is Students' appraisal of their satisfaction or dissatisfaction with learning experience in clothing and textiles in Tertiary Institutions in Delta State. To carry out this research work, two research questions and one hypothesis were raised to give direction to the research. A random sample of 198 students was selected from the target population of 660 Students enroll in the Four Tertiary Institutions in Delta State. However, a sample size of 157 students was used based on 157 usable questionnaires that were returned. The study adopted a descriptive survey design. A structured questionnaire titled (HESAIQ) was the instrument used for data collection. The data collected were analysed using simple means, standard deviations and one way analysis of variance. Findings revealed that Home Economics students in Tertiary Institutions in Delta State expressed satisfaction with the learning experiences and the Institution of the students' influenced their level of satisfaction. Students from Federal College of Education Technical, Asaba with mean score of 56.96 were more satisfied with their learning experiences. Based on the findings recommendations were made.
\end{abstract}

\section{INTRODUCTION}

Clothing and Textiles is one of three major aspects of Home Economics taught as part of the curriculum in Tertiary Institutions. Appraisal of instruction or courses by students have become commonplace in many universities and colleges in industrialized countries like the United States of America, Canada, Australia, Murray (1984). Although, the case is quite different in the Nigerian Education system, the use of students' in the appraisal of instruction is yet to be fully adopted (Arubayi 2000, 2003). Students' appraisal is very valuable, especially since the students are the direct consumers of the educational process.

Clothing and Textiles as a subject in the curriculum of Home Economics in Tertiary institutions is basically characterized by numerous activities and is skill oriented. Arubayi (2004) opined that Clothing and Textiles is a field of knowledge which combines both theoretical and practical knowledge from other subject areas like Arts and Sciences in the use of apparel to create an acceptable illusion on the wearer,family and society. This field of knowledge which is "activity" and "skill" oriented requires careful planning, selection and organization of learning experiences that will help the individual acquire skills, knowledge, abilities and attitude needed for self-reliance. One of the competencies required by the Home Economics teacher is the ability to make sound judgement in the selection of learning experiences from the wide range of knowledge available. How well a teacher plans, selects and organizes learning experiences is determined by the competence and the philosophy of the teacher. Olaitan and Agusiobo (1981) described the competent Home Economics teacher as a guide, a director and a supervisor of students' activities and not just purveyor of knowledge.

One of the responsibilities of the teacher is the selection of learning experiences that will aid him or her in the actualization of the objectives of any teaching and learning situation. Arubayi (2003) defined learning experiences as those activities students will perform during the teaching and learning situation that helps in the achievement of the set goals of any teaching process. Learning experiences are the activities in which students participate at school, home and in the community to help them clarify concepts. Learning experiences is next step in program planning after the objectives of a lesson is determined. Brubaker (1974) listed the following as consideration for selecting learning 
experiences, the concept to be taught; variety; the needs and abilities of students; interest and maturity levels of students; the degree of student participation possible, the number of senses involved, the time and season of the year; the suitability of the location where the activities are to be carried out; the equipment and facilities that are needed and available, the administrator's attitudes and the teacher's experiences and competence in guiding certain types of activities.

Clothing and Textiles is "practical and skill" oriented, it is imperative that the teacher of this subject should not only be knowledgeable in subject matter but resourceful, skillful and creative in the careful planning, selection and organisation of learning experiences tailored towards the actualization of the set goals of the teaching process. Okorie (2000) defined "skill" as an organised sequence of action proficiency executed and usually displaying a flexible but systematic temporal patterning. Skill is the ability to do something competently and this can only be acquired through learning and practice.

\section{Problem Statement}

The role of the teacher is "void" without students' as they are the major observers of the teachers in the classroom, therefore they will be in the best position to appraise the type of learning experiences selected and used by the teachers. The students' will be able to provide useful information as to whether they are satisfied or dissatisfied with the learning experiences selected and used in teaching. Are the learning experiences planned for and selected providing opportunity for students to have enough learning experiences that stimulate practice for proficiency and self reliance? Are the students satisfied or dissatisfied? It is the hope of the researcher that the answer to the research questions and hypothesis will throw light into the problem of students' satisfaction or dissatisfaction with the learning experiences.

\section{Questions/Hypothesis}

To do this, the research work seeks to provide answers to the following research questions/ hypothesis

\section{Questions}

1. How do the students appraise the learning experience used in Clothing and Textiles? 2. Are they satisfied or not?

\section{Hypothesis}

There is no significant difference between and within the appraisal of students as to their satisfaction and dissatisfaction of the learning experiences used in Clothing and Textiles.

\section{Scope and Delimitations of the Study}

This study is delimited to Home Economics students' in Tertiary Institutions in Delta State only. Delimitation is that the study is focussed on Home Economics students in the 2004/2005 academic session in Tertiary Institution in Delta State. This study seeks to find out the level of students' satisfaction and dissatisfaction with the learning experiences used in the teaching of Clothing and Textiles.

\section{MATERIALS AND METHODS}

This study adopted a descriptive survey research design. The target population of the study is made up of 660 students enrolled in Home Economics Programme in Tertiary Institutions in Delta State, Nigeria. The four Tertiary Institutions that made up the population of the study were College of Education, Warri; College of Education, Agbor; Federal College of Education Technical, Asaba; and Delta State University, Abraka.

A random sampling technique was used to select 198 students which made up $30 \%$ of the target population. This ensured proportional representation from each institution. This $30 \%$ is more than the minimum of $10 \%$ recommended by Roscoe (1975). The instrument used for the collection of the data was a structured questionnaire titled Home Economics students Appraisal of Instruction (HESAIQ). The instrument had a reasonable face and content validity and reliability coefficient of 0.78 using the test-retest method which was high enough to support the use of the HESAIQ in the research (Inomiesa 1993). In all, $157(80 \%)$ useable and duly completed questionnaires were returned. The return rate was adjudged to be reasonably high.

The data were analysed using simple means and one way Analysis of Variance (ANOVA). The result of the Analysis has been summarized in Tables 1 and 2 . 
Table 1: The difference of students Appraisal of their satisfaction or dissatisfaction with learning experiences in Clothing and Textiles

\begin{tabular}{lrrr}
\hline Institution & $N$ & Mean & Sd \\
\hline Warri & 51 & 52.37 & 12.1 \\
Agbor & 44 & 55.91 & 6.60 \\
Asaba & 26 & 56.96 & 7.32 \\
Abraka & 36 & 52,78 & 10.04 \\
\hline & 157 & 54.23 & 9.69 \\
\hline
\end{tabular}

Reported in table 1, are the mean scores and standard deviations of the respondents on their appraisal of their satisfaction or dissatisfaction with their learning experiences in Clothing and Textiles. The result revealed a general mean score of 54.23 out of a maximum obtainable mean of 70 . This gave an indication of satisfaction with their learning experiences. The degree of satisfaction was in the following descending order of mean scores. College of Education Technical Asaba, 56.96; College of Education, Agbor, 55.91, Delta State University, Abraka 52.78 and College of Education, Warri, 52.37. Though the students reported that they were satisfied there were however differences in the degree of satisfaction.

Analysis of variance test (ANOVA) was utilised to test the hypothesis of no significant difference in the means as presented in Table 2. The result revealed a calculated F. ratio of 2.07. The F - Ratio was found to be lower than the critical table F-Value of 3.00 with 156 degrees of Freedom at 0.05 level of probability. The hypothesis of no significant difference was therefore retained.

\section{DISCUSSION}

Findings from this research work have revealed that students have expressed satisfaction with the learning experiences, selected in the schools. This was revealed in the computed means of 56.96, 55.91, 52.78 and 52.37 for Asaba, Agbor, Abraka and Warri, respectively. The students from the Federal College of Education Technical Asaba had the highest mean score of 56.96 which by interpretation were more satisfied with their learning experiences. This finding came as no surprise as this institution of learning is Federal owned and a specialty school which is technically inclined. This finding is in support with an earlier finding by Arubayi (2006) that the Federal College of Education in Nigeria were better equipped, with more teaching and learning facilities, more qualified teachers, and with better funding for their Home Economics programme.

Raynesten (1999), also is of the opinion that there are some special qualities in the school environment such as adequate staffing, laboratories, equipment, teaching methods and styles that make individuals or groups to appraise learning activities or environment more favourable than another. Thus, the teachers from such school environment were better equipped to select and use learning experiences that were appropriate, adequate and challenging enough to motivate students' level of satisfaction. However, the students were all satisfied with the learning experiences used, the computed means revealed a difference with the level of satisfaction.

\section{CONCLUSION}

Arising from this research work one may conclude that students from Tertiary Institutions in Delta State Nigeria have expressed satisfaction with the learning experiences planned for selected and used in the teaching of Clothing and Textiles irrespective of their institutions of learning. Another conclusion is that institutions with special qualities such as adequate and competent staff are better able to plan select and organise learning experiences.

\section{RECOMMENDATIONS}

The main purpose of teaching Clothing and Textiles in Schools is to equip learners with "Saleable" skills needed for self-reliance. Thus it

Table 2: Analysis of variance (ANOVA) for significant test of difference with learning experiences in clothing and textiles

\begin{tabular}{lrrrrr}
\hline Sources & Df & \multicolumn{1}{c}{ SS } & MS & F. Ratio & Table \\
\hline Between Group & 3 & 569.90 & 189.97 & $2.07 *$ & 3.00 \\
Within Groups & 153 & 14068.74 & 91.95 & & \\
\hline Total & 156 & 14638.64 & XXXXX & & \\
\hline
\end{tabular}

*Non-Significant at the 0.05 level of probability 
is very important for institutions of higher learning to provide adequate learning environment with adequate facilities, competent staff and well funded programmes to enable the teachers select and use learning activities that will provide opportunities for skills to be practised, thus helping to concretize learning and make learning meaningful and purposeful.

\section{REFERENCES}

Arubayi DO 2000. Class Levels and Relevance of Home Economics and Education courses to a Degree Programme. Journal of Education and Society. $3(2): 41-46$

Arubayi DO 2003. Improvement of Instruction and Teacher Effectiveness in Tertiary Institutions: Are Students' Rating Reliable and Valid? Paper presented at $4^{\text {th }}$ Inaugural Lecture of Delta State University, Abraka, Delta State, Nigeria.

Arubayi DO 2006. Student Enrolment, Academic Staff
Quantity, and Teachers Students Ratio in Home Economics in Colleges of Education in Nigeria, DELSU Journal of Educational Research and Development. 5(1): 114-121.

Brubakar DL 1974. The Teacher as a Decision-maker. Dubuque IOWA: WM.C. Brown Company Publishers. Inomiesa EA 1993. Developing Primary School Science Test for Continuous Assessment of Primary Six Pupil. Review of Education, 13: 15-26.

Murray MD 1984. The Impact of Formative and Summative Evaluation of Teaching in North American University. Assessment Evaluation on Higher Education, 9(2):17-23.

Okorie JU 2000 .Vocational Industrial Education. Owerri: League of Researchers in Nigeria.

Olaitan S, Aguisobo O 1981. Introduction to the Teaching of Home Economics. Chichester,. John Wiley and Sons Limited.

Raynester E 1999. Students Learning and Perception of the Academic Environment: Higher Education, 13: 301-311.

Roscoe JT 1975. Fundamental Research Statistics for Behavioural Sciences. Holt Runehard and Winston, Inc. 